\title{
Effect of Integrated Plant Nutrient Management on Leaf N, P, K of Guava (Psidium guajava L.) cv. Allahabad Safeda
}

\author{
Porismita Dutta*, Utpal Kotoky and Kaushik Das
}

Department of Horticulture, Assam Agricultural University, Jorhat-785013, Assam, India

*Corresponding author

\section{A B S T R A C T}

\section{Keywords \\ IPNM, Vermicompost, Zinc sulphate, Boric acid, Microbial consortium \\ Article Info \\ Accepted: \\ 16 August 2018 \\ Available Online: \\ 10 September 2018}

An experiment was conducted to study the "Integrated Plant Nutrient Management in Guava (Psidium guajava L.)" cv. Allahabad Safeda in the Experimental Farm and Laboratory, Department of Horticulture, Assam Agricultural University, Jorhat during 2015-2017. A total of 9 (nine) treatments including a control with three replications and two seasons were laid out in a Randomized Block Design. During the period of investigation, the treatments showed varied response to leaf $\mathrm{N}, \mathrm{P}, \mathrm{K}$. Treatment $\mathrm{T}_{8}(\mathrm{Half}$ of $\mathrm{RDF}+10 \mathrm{~kg}$ Vermicompost $+100 \mathrm{~g}$ microbial consortium $+0.4 \% \mathrm{ZnSO}_{4}+0.4 \% \mathrm{H}_{3} \mathrm{BO}_{3}$ ) recorded the highest leaf $\mathrm{N}(1.54 \%), \mathrm{P}(0.44 \%)$ and $\mathrm{K}(0.39 \%)$.

\section{Introduction}

Guava (Psidium guajava L.), "the apple of tropics" is one of the most important fruit crop. It is a sub-tropical fruit, because of its high nutritive value and possibilities of cultivation even under adverse conditions. The fruit is native to Tropical America, stretching from Mexico to Peru, and were domesticated more than 2000 years ago. It was introduced by the Portuguese in India during $17^{\text {th }}$ century. In India, its position is fourth after mango, banana and citrus in terms of area and production. The area under guava cultivation in the country is 1078 thousand hectares with a production of 11147 thousand metric tons (NHB, 2015). Guava occupies about 14.92 per cent of the total area under fruits and accounts for about 12.5 per cent of the total fruit production in India. Guava occupies a place of considerable importance in the fruit economy of the country.

Guava trees are prolific bearer and to maintain its vigour, growth and productivity for a long time, it needs proper nourishment. Without proper management, continuous fruit production reduces nutrient reserves in the soil and thus, affects crop growth and productivity adversely. Replenishment of lost quantities of the nutrients is, therefore, necessary to maintain the fertility status of the soil and to get good crop in the following years. Therefore, a careful management is required to produce a profitable crop which includes cultural practices and obviously the 
fertilization and nutrition of orchard. Nutrition is most important factor affecting growth, yield and quality of a crop. Unless, it is maintained at an optimum level, higher yield and better fruit quality cannot be maintained. However, the increasing cost of fertilizers and their adverse effects on soil all over the world have made it necessary to think in terms of supplementing the soil with alternative sources which render soil more productive and gave higher yield and better quality (Srivastava, 2008).

Over the years, the concept of integrated plant nutrient management (IPNM) system is gaining momentum in India with arising threat to the food and nutritional security and loss of natural resources particularly during the last five decades. Integrated plant nutrient management (IPNM) refers to maintenance of soil fertility and plant nutrient supply to an optimum level for sustaining the desired crop productivity through optimization of the benefits form all possible source of plant nutrient in an integrated manner. It involves proper combination of chemical fertilizers, organic manure and biofertilizers suitable to the system of land use and ecological, social and economic conditions.

There is an urgent need for an alternative nutritional package to attain long term sustainability for fruit production as well as for maintaining soil health and productivity under IPNM system.

\section{Materials and Methods}

An experiment was conducted in the Experimental Farm and Laboratory, Department of Horticulture, Assam Agricultural University, Jorhat during 20152017. The experimental site was situated at $26^{\circ} 47^{\prime} \mathrm{N}$ latitude and $94^{\circ} 12^{\prime} \mathrm{E}$ longitude having an elevation of $86.8 \mathrm{~m}$ above mean sea level. The treatments comprising of $\mathrm{T}_{0}$ :
Recommended dose of fertilizers (RDF) and manures as control; $\mathrm{T}_{1}: \mathrm{T}_{0}+0.4 \% \mathrm{ZnSO}_{4} ; \mathrm{T}_{2}$ : $\mathrm{T}_{0}+0.4 \%$ Boric Acid; $\mathrm{T}_{3}: \mathrm{T}_{0}+0.4 \% \mathrm{ZnSO}_{4}+$ $0.4 \%$ Boric Acid; $\mathrm{T}_{4}$ : Half of $\mathrm{RDF}+20 \mathrm{~kg}$ FYM + 100g microbial consortium; $\mathrm{T}_{5}$ : Half of $\mathrm{RDF}+20 \mathrm{~kg} \mathrm{FYM}+100 \mathrm{~g}$ microbial consortium $+0.4 \% \mathrm{ZnSO}_{4}+0.4 \%$ Boric acid; $\mathrm{T}_{6}$ : Half of $\mathrm{RDF}+10 \mathrm{~kg}$ Vermicompost + $100 \mathrm{~g}$ Microbial consortium; $\mathrm{T}_{7}$ : Half of RDF $+10 \mathrm{~kg}$ Vermicompost $+0.4 \% \mathrm{ZnSO}_{4}+0.4 \%$ Boric Acid; $\mathrm{T}_{8}$ : Half of $\mathrm{RDF}+10 \mathrm{~kg}$ Vermicompost $+100 \mathrm{~g}$ microbial consortium + $0.4 \% \mathrm{ZnSO}_{4}+0.4 \%$ Boric Acid. The microbial consortium was the mixture of four different groups of biofertilizers (Phosphate solubilizing bacteria, Azotobacter, Azospirillum, and Rhizobium) in 1:1:1:1 ratio.

Among the chemical fertilizers, 500g: 1500g: $400 \mathrm{~g}$ NPK tree ${ }^{-1}$ was applied as control along with 20kg FYM. NPK along with FYM, Vermicompost and microbial consortium was applied in two seasons, one during the month of October 2015 and other during the last week of April 2016. The trees were sprayed with zinc sulphate $(0.4 \%)$ and boric acid $(0.4 \%)$ as per treatments, with the help of a hand sprayer. The sprays were given in November and May (single foliar spray). Rings were prepared at a distance of $1 \mathrm{~m}$ from the tree trunk for the application of fertilizers and manures. Observation on were presented in Table 1. The statistical analysis was carried out to know the variance for each parameter and effect of treatments using the standard procedure.

\section{Results and Discussion}

\section{Per cent leaf nitrogen}

In the present investigation, leaf nutrient contents in respect of nitrogen, phosphorus, potassium have given promising results. Effect of various treatments on leaf nitrogen content (\%) was found to be significant. The highest 
increase in leaf nitrogen content was recorded in $\mathrm{T}_{8}$ (Half of $\mathrm{RDF}+10 \mathrm{~kg}$ Vermicompost $+100 \mathrm{~g}$ microbial consortium $+0.4 \% \mathrm{ZnSO}_{4}+$ $0.4 \% \quad \mathrm{H}_{3} \mathrm{BO}_{3}$ ) while the lowest value was recorded in the control plants. These results were in close conformity with the Sen and Chouhan (1983) in pomegranate and Sarkar et al., (1985) in Aonla. The faster uptake and translocation of $\mathrm{N}$ from roots to leaves might be responsible for its greater accumulation in the leaves (Smith, 1962; Gammon and Shoemaker, 1964).

The increase in leaf nitrogen content might be due to the improvement in soil aeration, better soil moisture retention in root zone, increased microbial nitrogen fixation and, thus, improved the availability of macro and micronutrients. The addition of FYM might have improved the physical conditions of soil, root development and more soil moisture retention which resulted in increased absorption of water and nutrients and consequently improved the leaf nutrient status (Pattanayak et al., 2001 and Morselli et al., 2004). The greater availability of $\mathrm{N}$ from the compost applied which was reflected by the high value of $\mathrm{N}$ in the leaf. As the level of nitrogen in the leaves increased, the extra protein produced by conversion of the synthesized carbohydrates into amino acids in the leaf itself should have enabled them to grow larger in order to have a larger surface area for carbon assimilation (Russel, 1975) and this result in promoting better growth, development and yield in rainy season guava. Singh and Sharma (1993) reported that, Azospirillum (contained in microbial consortium) application had increased the $\mathrm{N}$ levels to almost the same extent of full dose of $\mathrm{N}$ and $\mathrm{P}$.

\section{Per cent leaf phosphorus}

Differences in the leaf phosphorus content due to different treatment were found significant. However the highest leaf phosphorus content was recorded with $\mathrm{T}_{8}$ (Half of $\mathrm{RDF}+10 \mathrm{~kg}$ Vermicompost $+100 \mathrm{~g}$ microbial consortium + $0.4 \% \mathrm{ZnSO}_{4}+0.4 \% \mathrm{H}_{3} \mathrm{BO}_{3}$ ) and the lowest in control plants during both the season. Similar finding had also been reported by Pereira and Mitra (1999) in guava. Singh and Sharma (1993) reported increased P level in leaf by application of different composition of bio and chemical fertilizers.

Table.1 Effect of IPNM on Leaf N, P, K

\begin{tabular}{|l|c|c|c|}
\hline Treatment & Nitrogen content (\%) & Phosphorus content (\%) & Potassium content (\%) \\
\hline $\mathrm{T}_{0}$ & 1.29 & 0.29 & 0.20 \\
\hline $\mathrm{T}_{1}$ & 1.32 & 0.30 & 0.30 \\
\hline $\mathrm{T}_{2}$ & 1.30 & 0.31 & 0.27 \\
\hline $\mathrm{T}_{3}$ & 1.33 & 0.34 & 0.32 \\
\hline $\mathrm{T}_{4}$ & 1.36 & 0.34 & 0.33 \\
\hline $\mathrm{T}_{5}$ & 1.35 & 0.39 & 0.36 \\
\hline $\mathrm{T}_{6}:$ & 1.39 & 0.38 & 0.34 \\
\hline $\mathrm{T}_{7}$ & 1.47 & 0.40 & 0.38 \\
\hline $\mathrm{T}_{8}$ & 1.54 & 0.44 & 0.39 \\
\hline Mean & 1.37 & 0.35 & 0.32 \\
\hline S.Ed & 0.011 & 0.007 & 0.010 \\
\hline CD-5\% & 0.024 & 0.015 & 0.021 \\
\hline
\end{tabular}

Initial leaf $\mathrm{N}: 1.29(\%), \mathrm{P}_{2} \mathrm{O}_{5}: 0.35(\%), \mathrm{K}_{2} \mathrm{O}: 0.30(\%)$ 
This might be due to the fact that phosphorus when applied to the soil in inorganic form get fixed up in the soil and is not readily available to the plant and is released to the plant slowly. Microbes present in the soil solubilize the fixed phosphorus and make it easily available to the plant (Sundara et al., 2002). In the present study, when phosphorus was given in combination with PSB, increased leaf phosphorus content might be due to more solubilization of phosphorus by PSB thus making more phosphorus available to the plant.. El Moniem and Radwan (2003) reported that, application of 75 per cent NPK + biofertilizers in William banana plants significantly increased the leaf macronutrient content.

\section{Per cent leaf potassium}

The difference in the level of leaf potassium due to different treatment was found to be highly significant. The highest leaf potassium content was recorded with treatment $\mathrm{T}_{8}$ (Half of $\mathrm{RDF}+10 \mathrm{~kg}$ Vermicompost $+100 \mathrm{~g}$ microbial consortium $+0.4 \% \mathrm{ZnSO}_{4}+0.4 \%$ $\mathrm{H}_{3} \mathrm{BO}_{3}$ ) and lowest in control plants during both the seasons. Nitrogen fixing biofertilizers secretes plant growth regulators in rhizosphere, which might have lowered the $\mathrm{pH}$ of the soil and thereby making $\mathrm{K}$ available to the plant easily. Chaudhary et al., (2003) also observed increase in $\mathrm{N}, \mathrm{P}$ and $\mathrm{K}$ content due to combined application of vermicompost and farmyard manure. The increased level of leaf potassium concentration had direct effect on the increased fruit yield. This might be attributed to the influence of leaf potassium on increasing rate of photosynthesis. The essentiality of potassium as an activator for enzymes involved in protein and carbohydrate metabolism is well established (Devlin, 1969).

From the above discussions it can be concluded that among all the treatments, treatment $\mathrm{T}_{8}$ (Half of $\mathrm{RDF}+10 \mathrm{~kg}$ Vermicompost $+100 \mathrm{~g}$ microbial consortium + $\left.0.4 \% \mathrm{ZnSO}_{4}+0.4 \% \quad \mathrm{H}_{3} \mathrm{BO}_{3}\right)$ recorded significantly the highest values for leaf $\mathrm{N}, \mathrm{P}$, K.

\section{Acknowledgement}

The author is grateful to Major Advisor, the Head, and all the faculties, Department of Horticulture for providing necessary facilities.

\section{References}

Chaudhary, R. S., Das, A. and Pattnaik, U. S. (2003). Organic farming for vegetable production using vermicompost and FYM in Kokriguda watershed of Orissa. Ind. J. of Soil Cons., 31(2): 203-206.

Devlin, R.M. (1969). Plant physiology. Van Notrand Reingold Company, $2^{\text {nd }}$ ed., New York press. p. 58.

El-Moniem, E. A. A. A. and Radwan, S. M. A. (2003). Response of William banana plants to biofertilization in relation to growth, productivity and fruit quality. Arab Univ. J. of Agril. Sci., 11(2): 751763.

Gammon, N. and Shoemaker, T. S. (1964). Effect of fertilizer on mineral levels in leaves of Flordasun peach. Proceedings Fla Station Hort. Society. 76: 380-384.

Morselli, T.B.G.A., Sallis, M.D.G., Terra, S. and Fernandes, H.S. (2004). Response of lettuce to application of vermicompost. Revista Cien. Rural. 9(1): 1-7.

Pattanayak, S. K., Mohanty, R. K. and Sethy, A. K. (2001). Response of okra to Azotobacter and Azospirillum inoculation grown in acid soil emended with lime and FYM. $2^{\text {nd }}$ North Eastern Regional Conference on Biofertilizer, AAU, Jorhat Assam, p. 35. 
Pereira, L. S and Mitra, S. K. (1999). Studies on organic along with inorganic nutrition in guava. Ind. Agricl. 43(3-4): 155 - 160.

Russel, E.W. (1975). Soil conditions and plant growth. ELBS and Longman. ed. $10^{\text {th }}$, p. 327.

Sarkar, G. K., Sinha, M. M. and Mishra, R. S. (1985). Nutritional status in Aonla cv. 'Banarasi' Prog. Hort.17: 41-47.

Sen, N.L. and Chauhan, K.S. (1983). Effect of different NPK fertilization on physicochemical characters of pomegranate. Pun. Hort. J., 23: 59-63.

Singh, C. and Sharma, B.B. (1993). Leaf nutrient composition of sweet orange as affected by combined use of bio and chemical fertilizers. South Ind. Hort. 41: 131-134.

Smith, C. B. (1962). Mineral analysis of plant tissues. Annual Review of Plant Physiology. 13: 81-103.

Srivastava, A.K. (2008). Recent initiative in Horticulture (Eds: K.L. Chadda, A.K. Singh and V.B. Patel). The Horticulture society of India, New Delhi. Malhotra Publishing House, New Delhi. pp. 324333.

Sundara, B., Natarajan, V. and Hari, K. (2002). Influence of phosphorus solubilizing bacteria on the changes in soil available phosphorus and sugarcane and sugar yields. Field Crops Res. 77(1): 43-49.

\section{How to cite this article:}

Porismita Dutta, Utpal Kotoky and Kaushik Das. 2018. Effect of Integrated Plant Nutrient Management on Leaf N, P, K of Guava (Psidium guajava L.) cv. Allahabad Safeda. Int.J.Curr.Microbiol.App.Sci. 7(09): 2109-2113. doi: https://doi.org/10.20546/ijcmas.2018.709.257 